\title{
Ethnopsychological aspects of the meaning-of-life and value orientations of Armenian and Russian students
}

\author{
Asya S. Berberyan ${ }^{a \star}$, Hermine S. Berberyan ${ }^{\mathrm{b}}$ \\ a Psychology chair, Russian-Armenian (Slavonic) University, Yerevan, Armenia \\ ${ }^{\mathrm{b}}$ Faculty of Social Sciences, National Research University Higher School of Economics, Moscow, \\ Russia
}

*Corresponding author. E-mail: aspsy@inbox.ru

The study of ethnocultural identity is remarkably up to date when considering the interactions of different countries, the ethnic groups studied within the limits of mono- and multicultural space, and the processes of acculturation, assimilation, and others. Ethnocultural identity is based on the desires of the individual and the nation viewed integrally; it is achieved in substituted forms through integration in the cultural and symbolic space of society. The aim of this article is to analyze the meaning-of-life and value orientations of Armenian and Russian students in the Russian Federation and the Republic of Armenia. In order to study ethnocultural identity as part of the self-concept we carried out a study with students at the Russian-Armenian (Slavonic) University (Yerevan, Armenia) and the South Federal University (Rostov-on-Don, Russia): at the initial stage we conducted two focus groups (the number of respondents in each group was 10); at the second stage we conducted a study the number of respondents was 160. When the Armenian and Russian youth described their ethnicity, high values of social self - in particular, national civic identity - correlated with high and medium levels of meaning-of-life orientations. Armenians and Russians in title ethnos and in the associated diaspora had a number of similarities and differences in value orientations. The majority of respondents in the focus groups noted their positive emotions connected with being Armenian or Russian. The ethnic Russians in Armenia pointed out the ease of communication with Russian speakers, regardless of ethnicity, but noted the difficulty of social interaction because of their insufficient knowledge of the Armenian language. The formation and development of ethnic self-consciousness may be carried out at two levels: understanding the values and ideas of ethnicity and assessing the ethnocultural and ethnopsychological features of one's ethnic group. The ethnic identity of Armenians in Russia has been transformed, and they are now characterized by similar values as ethnic Armenians in Armenia. Ethnic Armenians and ethnic Russians are in continuous interaction in Armenia and in Russia. This interaction is a key to positive ethnic attitudes in both groups as evidenced by their tolerance for other ethnic groups and their solidarity and it enriches the representatives of both ethnic groups at the regulatory value level, making them carriers of both culture.

Keywords: ethnocultural identity, meaning-of-life orientations, value orientations 


\section{Introduction}

\section{Theoretical and methodological framework}

Over the past several decades the problems of ethnic identity have come to the fore because of people's desire for the preservation and development of their unique cultures.

The study of identity as a mechanism of adaptation within unconscious processes is a significant contribution made by the representatives of the classic psychoanalytic school: S. Freud, A. Adler, J. Bowlby, M. Klein, M. Müller, U. Meissner, J. Piaget, H. Sullivan, A. Freud, K. Horney, R. Shafer, Karl G. Jung (Bowlby, 1969; Guntrip,1971; Sullivan, 1949/2000). Of special significance was the impact of E.H. Erikson on the formation of the concept of identity, as well as on the use of the term in the context of multidisciplinary scientific knowledge (Erikson, 1968). Such Russian and international authors as G. Berry, M. Plizent, D. Taylor, G. Tedzhfel, G. Marcia, T.G. Stefanenko, Y.P. Platonov, G.U. Soldatova, L.M. Drobizheva, B.D. Parigin, L.G. Pochebut, V.Y. Khotinets, N.M. Lebedeva, and A.N. Tatarko conducted studies of ethnic identity and the essence of its structural components (Pochebut, 2012; Soldatova, 1998; Stefanenko, 2000). Soldatova (1998, p. 43) said about the ethnic identity: "On the one hand, ethnic identity is narrower than ethnic self-consciousness. It is the cognitive-motivational core of ethnic self-consciousness. On the other hand, it is wider, because it contains in itself a layer of the unconscious".

The theories forming the methodological framework for analyzing the concept of meaning are the following: personalistic theory: J. Lacroix, P. Lundberg, R.Ricker, W. Stern; humanistic theory: A. Maslow, C. Rogers, D. Royce, A. Powell, F. Phoenix; existential theory: J. Bugental, V. Frankl(Bratchenko, 2001; Frankl, 1992; Rogers, 1959).General psychological theories that laid the foundations for the psychology of the meaning of life rely on the meaning-of-life approach to understanding human representation; these theories were devised by L.S. Vygotsky, A.N. Leontiev, B.V. Zeigarnik, O.K. Tikhomirov, A.G. Asmolov, I.V. Dubrovin, V.P. Zinchenko, V.A. Ivannikov, D.A. Leontiev, V.V. Stolin, E.V. Subbotsky (Asmolov, 2007; Leontiev,1975; Vygotsky, 2005).

\section{Relevance of the research}

Studies of Armenian and Russian youth have been carried out by both Russian and Armenian psychologists. Recent cross-cultural research on young ethnic Armenian and Russian representatives of their ethnic groups in their own countries and in the associated diaspora are reflected in the works of Russian and Armenian psychologists: A.K. Belousova, V.G. Krysko, A.A. Nalchajyan, A.S. Berberyan, M. Vardanyan, O.R. Tuchina, and others(Berberyan, 2012; Berberyan, Tuchina, 2014,Krysko, 2008; Nalchajyan, 2010).

Our work is relevant because of blank spots in the theoretical analysis of the concept of ethnic identity and the factors that determine its formation and development, the lack of quantitative and qualitative indicators as part of the empirical research, and the lack of psycho-pedagogical support at the level of psychological services in the context of ethnic identity. 
The object of our research was to examine the psychological characteristics of ethnocultural identity in a sample of Armenian and Russian youth in Russia and Armenia. The subject of our research is the phenomenon of ethnocultural identity in the aggregate, its intrinsic and functional specificity, and its structural parameters and historical forms. Our aim was to study the meaning-of-life and value orientations as well as the professional orientations of Armenian and Russian students in the Russian Federation and the Republic of Armenia. Cross-cultural studies of this kind are the latest trends for the disclosure of the psychological characteristics of ethnic Armenians and Russians in Armenia and of ethnic Armenians and Russians in the Russian Federation.

The theoretical significance of our work lies in our deep theoretical analysis of the concepts of ethnocultural identity, the meaning of life, and values in the works of Russian, Armenian, and foreign psychologists. The practical significance of our work lies in the possible future implementation of the results of cross-cultural study we conducted and interpreted with a use of qualitative and static processing (by SPSS) in coming to our conclusions.

\section{Background of the research}

Identity is a dynamic structure developing nonlinearly and defined by the aspiration of the individual toward integrity and uniqueness. Ethnic identity is composed of personal characteristics that reveal a personality that is developing through the awareness and self-understanding of the ethnic identity in the context of global sociopolitical changes in society. Ethnocultural identity is self-identification with an ethnic community; it is based on ethnic values, self-understanding, and self-assessment of membership in a group. Ethnocultural identity can be seen as a complex, multilevel hierarchy that is transformed under the influence of global processes.

The personal nature of ethnic forms of culture leads to self-awareness and identity as a free person; the subject's own activities are endowed with value-semantic features. At a young age the value-sense aspect can develop in productive and reproductive situations. The main characteristics of this productive, active, and creative development of the semantic sphere are its "openness, reflexivity, as a consequence, ordering, non-stereotype, harmony," willingness to follow the call of potential, and "flexibility of consciousness as a core center" (Abakumova, 2003, p. 98).

The ethnic and cultural diversity of modern society, in spite of the intense flow of information and globalization processes, covers virtually the entire civilized world. This phenomenon was dubbed by scientists the "ethnic paradox of our time" (Stefanenko, 2000), which is manifested in the simultaneous "co-existence" of globalization and civilization and of the spiritual and material culture of ethnic communities in the context of a surge of interest in ancient rituals, customs, and folklore.

The concept of identity in the interpretation of research has a multifaceted and broad meaning. It is part of the dichotomy of social/personal, and it adds to, updates, and often replaces the traditional ideas of self-concept, self-image, and "selfand-others. Based on the logic of the theoretical analysis, the concepts and methodological principles for the study of identity are the same as the principles for the study of personality. 
The concept of identity was presented in detail in the work of the famous psychologist Erik Erikson (1968); he outlined the scale of the notion by arguing that identity crises go far beyond philosophical and socio-psychological study and present an interdisciplinary problem.

J. E. Marcia (Marcia, Waterman, Matteson, Archer, \& Orlofsky, 1993) suggested the model of identity status; he defined identity as a special structure of the Ego, the internal, self-creating, dynamic organization of abilities, beliefs, and individual stories. In our view, Marciass suggestion that this structure is revealed through patterns of solving problems is important.

According to this approach, solving any problem, even the most insignificant, helps people realize personal characteristics and the meaningfulness of their lives in the formation of identity. If we link this approach to the development of identity, we can claim that in the process of becoming a person a number of problems associated with the social environment, like privacy and self-determination, in the system of the value-oriented sector are solved.

The determination and value-willed aspects are the main focus of A.S. Waterman's work (1999), where he defines a direct correlation between identity and a system of goals, values, and beliefs that act, according to Waterman, as "elements of identity": identity, moratorium, premature identity, diffuse identity. The formation of the model of ethnic identity by Marcia and colleagues(1993) is interesting for the purposes of our study because the model takes into account two criteria: (1) the presence or absence of a crisis; (2) the presence or absence of student-significant goals, values, and beliefs.

We consider the theory of identity as being in the psychological research paradigm of personal identity. However, many authors believe that traditional psychoanalysis is not in a position to fully present identity because it does not use the category of social protection. Methods of psychoanalytic reasoning and consideration of the environment as the "outside world" or the "objective world" do not take into account its total reality. Thus, we can conclude that psychological science, in the presence of various typologies, underrepresents the relationship between different kinds of identity that would allow for the basic problem of self/society.

An integral part of the social identity of a person is the notion of ethnic identity. It implies awareness of belonging to a certain ethnic community. According to Stefanenko (2000), ethnic identity is first and foremost the result of cognitiveemotional awareness of oneself as a representative of the ethnos and is also the result of a certain degree of identification with the ethnos and separation from other ethnic groups.

Among many definitions, we would like to highlight that of Shpet (1996), who regards ethnic identity as the experience of identity with one ethnic community and separation from another. This definition implies that the structure of identity consists of two components: (1) a cognitive understanding of the hallmarks of one's own group, and (2) the attribution of oneself to it on the basis of ethno-differentiating symptoms and affects (an assessment of one's group and an emotional attitude toward membership in it).

Ethnic identity is not only an awareness of identity with a certain group but also one's evaluation of it and one's emotional attitude and feelings toward it. According to Soldatova (1998, p. 49, "Dignity, pride, resentment, fear are important criteria of 
interethnic comparisons. These feelings are based on a deep emotional connection with the ethnic community and moral obligations toward it, which emerge in the process of the socialization of an individual".

We can define identity as a dynamic structure that develops nonlinearly and is predicated on the desire of the individual for uniqueness and integrity. In relation to the members of an ethnic community, one may have both positive and negative attitudes. The nature of this relationship is affected by many factors, including one's importance and ethnosocial status. It has been found that some members of nonRussian ethnic groups in Russia perceive their groups as more attractive because higher status is associated with an increase in self-esteem and pride in their people (Berberyan, 2012).

Factors affecting the formation and expression of ethnic identity are the following:

(1) subjective factors of individual human life

(2) global sociopolitical changes in a country

(3) the heterogeneity/homogeneity of the ethnic environment

(4) ethnic and cultural distance

In many studies on the development of ethnic identity, the results show a trend among the members of minority groups to identify themselves with the dominant group; such identification is connected to children's early awareness of the social structure in a society. The focus on "intra-orientation" usually occurs with age and the development of ethnic identity in the ethnic minority. An individual may identify himself with two social groups: - a majority group and a minority group; regardless of individual's own nationality, and despite the assignment of a particular group either of them may become socially desired (or a point of reference).

The consideration of ethnic identity as a personal characteristic will reveal potential personality development through young people's awareness and self-understanding of their ethnic identity in the context of global social-political changes in the society. We know that the impact of social context on ethnic identity depends on whether a person lives in a mono-ethnic or multiethnic environment. However, few studies have been conducted on the differences in the self-identity and the selfattitude of people living in different ethnic environments.

D.A. Leontiev (2003) defines the semantic aspect of a person as a specially organized set of semantic structures and the relationships between them; these structures ensure the coherent semantic regulation of the vital activity of the person in all its aspects". In the end, the meaning of our existence really is understanding, and the main purpose of the subject is to search for the meaning of life, to understand it. Understanding the world, a person has to understand itself not as an object and has to recognize the inside from the perspective of the meaning of existence"(Znakov, 2000, p. 15).

\section{Hypothesis}

Our general hypothesis was that high valuation of the social self - in particular, self-described national-civic identity - correlates with high and medium levels of general life orientations in Armenian and Russian youth. Our local hypotheses 
were the following: (1) According to the methodology of personal semantic differentials, the power factor is higher in both groups of ethnic Russians, and the activity factor is higher in the groups of ethnic Armenians. (2) Ethnic Armenian youth when describing themselves don't use the component of the "past," which correlates with a high level of anxiety. (3)The cognitive and affective components of the national identity of most Armenian and Russian students stipulate the adoption of national heroes as reference groups.

\section{Method}

\section{Subjects}

We conducted a study of ethnic Armenian and Russian student youth in the Russian Federation and the Republic of Armenia; the total number of respondents was160. The subjects were divided into four groups: (1) the titular group of ethnic Armenians, (2) ethnic Armenians of the diaspora in Russia, (3) the titular group of ethnic Russians, (4) ethnic Russians of the diaspora in Armenia. Answers to a questionnaire on the awareness of ethnicity, in which respondents described their family tree, confirmed this division along ethnic lines.

\section{Observation \& testing}

Methods chosen for the study were the following four tests and one questionnaire:

\section{Life Meaning Orientations Test (D.A. Leontiev)}

This test is an adapted version of the Purpose-in-Life Test of James Crumbaugh and Leonard Maholick. The method was developed on the basis of Frankl's (1992) desire for meaning and logotherapy theory, and its aim was to validate this theory's components. The Russian version, the Meaning-of-Life Orientations Test, was developed on the basis of factor analysis and adapted by D.A. Leontiev in 1968-1988. In addition to being an indicator of general life meaningfulness, it comprises five subscales reflecting three concrete meaning-of-life orientations (purposes in life, life process or interest and emotional saturation, life productivity or satisfaction of self-realization) and two aspects of the locus of control (control locus-self, control locus-life). The first three factors form meaning-of-life orientations: purposes in life (the future), life process (the present), and satisfaction of self-realization (the past). The two remaining factors characterize the locus of inner control as a general ideological conviction that self-control is possible.

The following five subscales are used in the test:

Purposes in life. Scores on this scale characterize future purposes' presence or absence in the respondent's life; these purposes fill life with meaning, intention, and time perspective. Even if the general life-meaningfulness level is high, low scores on this scale indicate a person who lives in the present or even in the past.

Life process or interest and emotional saturation. The content of this scale coincides with the famous dictum that the only meaning of life is to live. 
It shows whether respondents perceive their life processes as interesting, emotionally saturated, and meaningful.

Life productivity or satisfaction of self-realization. Scores on this scale reflect respondents' estimates of their past, their sense of previous productivity and meaningfulness in life.

Locus of control-self (master of life). High scores correspond to respondents' conceptions of themselves as strong people, with sufficient freedom of choice to build their lives in accordance with their own goals and objectives and understanding of the meaning of life. Low scores correspond to respondents' frustration in attempting to control the events of their lives.

Locus of control-life. High scores indicate respondents' belief that they have control of their lives and are free to make decisions and to implement them. Low scores indicate fatalism, the belief that human life is not subject to conscious control, that freedom is illusory, and that it is pointless to think about the future.

\section{2. "Personal Semantic Differential" Method}

This method was developed on the basis of the modern Russian lexicon and is characterized by ideas formed in our culture about the structure of personality. The semantic-differential technique was developed by C. Osgood in 1957 and has since been widely used worldwide in psychological diagnostics. Personal Semantic Differential method was modified by employees of the V.M. Bekhterev Psychoneurological Institute. The method gives respondents the opportunity to explore their attitudes toward themselves and others; it is based on identifying individuals' representations of self-importance, level of claims, volitional self-regulation, and communication skills in the development of interpersonal relations. Originally 120 words denoting personality traits were chosen from S. Ozhegov's Russian language dictionary. The final version of the method includes 21 personality traits. While interpreting the data obtained in the diagnostics by the Personal Semantic Differential method, we focused on the fact that subjective and emotional-semantic representations of oneself and others are reflected in these scales, as are interpersonal relationships; these representations can only partly correspond to reality, but they are of significance in themselves.

The developed version of the method involves three classical factor poles of the semantic differential: Assessment, Force, and Activity. Adjectives denoting personality are used as the scales' polar positions.

The Assessment factor indicates subjects' self-esteem, self-acceptance, recognition of their socially approved characteristics, critical attitude toward themselves, and self-satisfaction. Subjects with high values on this factor accept themselves, are aware of themselves as carriers of positive, socially approved characteristics, and in a certain sense are satisfied with themselves. Low scores indicate acritical attitude toward oneself, dissatisfaction with one's own behavior and level of achievement, and an insufficient level of self-acceptance. 
The Force factor in the self-assessment reflects the development of volitional sides. High values are an indicator of self-confidence and independence, as well as of the tendency to rely on one's own strength in difficult situations.

The Activity factor in the context of self-assessment is evidence of an extroverted personality. Positive values on this scale indicate high activity, sociability, impulsivity; negative values on this scale indicate high introversion, a certain passivity, and emotional reactions.

\section{Twenty Statements Test (M. Cun T. McPartland)}

This procedure asks for 20 answers to the question: "Who am I?" In this method of psychological diagnostics (nonstandardized self-description), the respondent can answer explicitly, although in some modifications options for answers are presented. The method was developed in 1954 by M. Cun and T. McPartland; several modifications of it are known.

The test is formed on the basis of Cun's idea of self-concept. The methodological bases of the idea are concepts of social roles and role behavior in which selfperception is formulated through the prism of role performance. This formulation is reflected in self-descriptions given by the respondents. The following categories are most commonly used for an analysis: type of relationships, class, character traits, interpersonal style, and aspirations of others. A respondent has 12 minutes to formulate 20 different answers to the question "Who am I?". Answers are given in the order in which they spontaneously come to mind. After that, the respondent evaluates each quality as positive, negative, or ambiguous, or uses a sign that means it is difficult to estimate.

The scale of identification characteristics includes 24 indicators that combine to form seven generalized components of identity: (1) social self (direct designation of sex, sexual role, educational and professional position, family affiliation, regional identity, ethnic identity, citizenship, ideological identity, group affiliation), (2) communicative self (friendship or circle of friends, communication or subject of communication), (3) material self (a description of owned property, evaluation of own security, attitude to the external environment), (4) physical self (a subjective description of physical data), (5) activity self (classes, activities, interests, self-assessment of activity ability), (6) perspective self (personal perspectives on and aspirations for social, communicative, material, physical, and activity selves), (7) eflexive self (personal identity, global self, existential self) and two separate indicators: identity problem and situational state.

\section{4. "Nonexistent Animal" projective method}

This projective method of personality diagnostics is based on psychomotor connection theory. It can be used to register a state of psyche, based on motility fixation in particular, motor drawing by the (dominant) right hand. The sheet of paper acts as a space model, and muscle condition fixes the attitude toward the space, the emerging trend. The space, in turn, is associated with the emotional overtone of the experience and the time periods of present, past, and future. The space is also connected with the effectiveness of the psyche's work. The space behind and to the left of the subject is connected with the previous time period and inactivity (lack of 
active communication between thought and performance, between planning and implementation). The right side, the space at the front and at the top, is related to a future time period and effectiveness. On the sheet the left side and the bottom are associated with negative and depressive emotions, uncertainty, and passivity. The right side (corresponding to the dominant right hand) is associated with positive emotions, energy, activity, concrete action.

In addition to these general laws of psychomotor connection and relationship to the space, theoretical rules of operating with symbols and symbolic elements and geometric shapes are used in the interpretation of the test material. The location of a drawing at the top edge of the sheet is interpreted as an indicator of high self-esteem (the closer to the top, the more pronounced the self-esteem is), contentment with one's position in society, activity, recognition by others, self-assertion. The location at the bottom of the picture indicates the opposite traits: self-doubt, low self-esteem, depression, indecision, lack of interest in one's position in society, lack of recognition, lack of self-assertion.

\section{The authors' questionnaire}

We developed this questionnaire on the basis of several Russian psychological profiles (Stefanenko,2000), Lebedeva and Tatarko,2011), to identify the characteristics of ethnocultural identity. The questionnaire contains 15 questions, including questions about factual data - "What is your name/surname?" "How long have you lived in Armenia/ Russia?" "What is your native language?" "What is the name of the city where you live?" - and questions requiring a subjective answer - "Which nationality do you refer yourself to?" "Is there is a second nationality that you refer yourself to?" "Please list qualities that in your opinion are ethno-integrating." "Describe your feelings about living in Armenia/Russia". These questions laid the base for interpreting the results of the empirical study on factual data and on affective and cognitive components.

\section{Design}

To investigate ethnocultural identity, we first used focus groups' method and then conducted a study with students at the Russian-Armenian (Slavonic) University (c. Yerevan, Republic of Armenia) and the South Federal University (Rostov-on-Don, Russian Federation).

In the first stage of the study we conducted focus groups in Armenia to identify the importance of the issues and to observe a wide variety of ethnic interactions in a single educational environment. The aim was to elicit ideas and thoughts about their ethnic identity from native Armenian students and Russian students in diaspora. The native language of the Armenian students was Armenian, and they had lived in Armenia for more than 15 years). The native language of the Russian students was Russian; they had lived in Armenia for over 5 years. The number of participants in each group was10; there were representatives of different courses of study and different educational levels. No gender differences were found in the two groups of respondents. 
The majority of respondents noted positive emotions in connection with their being Armenian or Russian . However, the Russians in Armenia celebrated their ease of interaction with Russian speakers, regardless of ethnicity; they also noted difficulties in social interactions because of their insufficient knowledge of the Armenian language. The Armenians revealed insufficient knowledge of traditions in contrast with the Russians. In some cases, they interpreted some native Armenian traditions and rituals in different ways and maintained, in particular, the tradition of the wedding. The importance of keeping traditions and performing rituals rather than having a semantic understanding of them prevailed when they spoke about such events as Trndez (Feast of Purification), Tsakhkazard (Palm Sunday), Vardavar (Water Day), and others. In the group of Armenians the overwhelming majority (85\%) had knowledge of the history of Armenia at an above-average level, while the Russians had an average knowledge of the history (knowledge of important dates only).

In the second phase of the study we tested four groups of respondents: ethnic Armenians in Armenia, ethnic Armenians in Russia, ethnic Russians in Russia, ethnic Russians in Armenia. Statistics of the samples is presented in Table 1.

Table 1.Descriptive statistics

\begin{tabular}{lc}
\multicolumn{1}{c}{ Respondents } & $N$ \\
\hline Sex: & \\
Male & 80 \\
Female & 80 \\
Age: & \\
$18-21$ & 85 \\
$22-25$ & 75 \\
Residence: & \\
Ethnic Armenians in Armenia & 51 \\
Ethnic Russians in Armenia & 29 \\
Ethnic Armenians in Russia & 40 \\
Ethnic Russians in Russia & 40 \\
Course of study: & \\
Arts and humanities & 79 \\
Natural sciences & 81 \\
Valid $N$ & 160 \\
\hline
\end{tabular}

\section{Results}

According to analysis of the questionnaire regarding awareness of ethnicity, a trend was observed among ethnic Armenians as well as among ethnic Russians :they identified themselves as representatives of the nationality to which they belonged because of genetic origin. 
The answers given to the next question - - What nationality would you prefer?" - are presented in Table 2.In all groups the subjective classification to their own nationality dominated (the affective component of ethnic identity).

Table 2. Nationality preference

\begin{tabular}{lcccc}
\hline $\begin{array}{l}\text { Which nationality } \\
\text { would you prefer? }\end{array}$ & $\begin{array}{c}\text { Ethnic Armeni- } \\
\text { ans in Armenia }\end{array}$ & $\begin{array}{c}\text { Ethnic Armeni- } \\
\text { ans in Russia }\end{array}$ & $\begin{array}{c}\text { Ethnic Russians } \\
\text { in Russia }\end{array}$ & $\begin{array}{c}\text { Ethnic Russians } \\
\text { in Armenia }\end{array}$ \\
\hline $\begin{array}{l}\text { Armenian } \\
\text { Russian }\end{array}$ & $91 \%$ & $93 \%$ & $0 \%$ & $1 \%$ \\
$\begin{array}{l}\text { No concrete } \\
\text { nationality }\end{array}$ & $0 \%$ & $2 \%$ & $92 \%$ & $90 \%$ \\
$N$ & $9 \%$ & $5 \%$ & $8 \%$ & $9 \%$ \\
\hline
\end{tabular}

Table 3 is the reflection of respondents' answers to the following questions: "What do you have in common with the people of your nationality?" and "On what grounds can a person's nationality be determined, in your opinion?". It means that ethno-integrating qualities, listed by respondents, are presented in Table 3.

Table 3. Ethno-integrating qualities

\begin{tabular}{|c|c|c|c|c|}
\hline & $\begin{array}{l}\text { Ethnic Armeni- } \\
\text { ans in Armenia }\end{array}$ & $\begin{array}{l}\text { Ethnic Armeni- } \\
\text { ans in Russia }\end{array}$ & $\begin{array}{c}\text { Ethnic Russians } \\
\text { in Russia }\end{array}$ & $\begin{array}{l}\text { Ethnic Russians } \\
\text { in Armenia }\end{array}$ \\
\hline \multirow{5}{*}{$\begin{array}{l}\text { What do you have } \\
\text { in common with } \\
\text { the people of your } \\
\text { nationality? }\end{array}$} & \multirow{3}{*}{$\begin{array}{l}\text { mentality }(46 \%) \\
\text { history, culture } \\
(29 \%)\end{array}$} & \multirow{3}{*}{$\begin{array}{l}\text { mentality }(46 \%) \\
\text { history, culture } \\
(33 \%)\end{array}$} & native language & \multirow{2}{*}{$\begin{array}{l}\text { native language } \\
(59 \%)\end{array}$} \\
\hline & & & $(29 \%)$ & \\
\hline & & & \multirow{2}{*}{$\begin{array}{l}\text { history, culture } \\
(28 \%)\end{array}$} & \multirow{2}{*}{$\begin{array}{l}\text { history, culture } \\
(28 \%)\end{array}$} \\
\hline & religion(7\%) & religion(8\%) & & \\
\hline & other $(18 \%)$ & other (13\%) & other (43\%) & other $(13 \%)$ \\
\hline \multirow{5}{*}{$\begin{array}{l}\text { On what grounds } \\
\text { can a person's } \\
\text { nationality be } \\
\text { determined, in } \\
\text { your opinion? }\end{array}$} & ethnicity(35\%) & ethnicity(41\%) & language (29\%) & language (30\%) \\
\hline & $\begin{array}{l}\text { temperament, } \\
\text { emotions }(23 \%)\end{array}$ & $\begin{array}{l}\text { temperament, } \\
\text { emotions }(23 \%)\end{array}$ & $\begin{array}{l}\text { ethnic origin } \\
(27 \%)\end{array}$ & $\begin{array}{l}\text { ethnic origin } \\
(29 \%)\end{array}$ \\
\hline & language (22\%) & language (23\%) & model of & model of behav- \\
\hline & religion (7\%) & religion (8\%) & behavior(15\%) & ior (15\%) \\
\hline & other $(13 \%)$ & other $(5 \%)$ & other (29\%) & other $(26 \%)$ \\
\hline
\end{tabular}

When asked about their reference groups, the majority of respondents $(87 \%$ of ethnic Armenians and 85\% of ethnic Russians) named national heroes, in most cases heroes of the Great Patriotic War, as their reference group.

Use of the «Who am I?» method revealed the categories listed in Table 4The majority of the respondents, both ethnic Armenians and ethnic Russians, in describing themselves, turned to their social and reflexive selves. The characteristics of their social self were mainly family identity, national and civic identity, educational and professional position. 
Table 4.Categories of answers to the question "Who am I?"

\begin{tabular}{lcccc}
\hline \multicolumn{1}{c}{ “Who am I?” } & $\begin{array}{c}\text { Ethnic Armeni- } \\
\text { ans in Armenia }\end{array}$ & $\begin{array}{c}\text { Ethnic Armeni- } \\
\text { ans in Russia }\end{array}$ & $\begin{array}{c}\text { Ethnic Russians } \\
\text { in Russia }\end{array}$ & $\begin{array}{c}\text { Ethnic Russians } \\
\text { in Armenia }\end{array}$ \\
\hline Social self & $35 \%$ & $37 \%$ & $39 \%$ & $33 \%$ \\
Communicative self & $12 \%$ & $7 \%$ & $11 \%$ & $0 \%$ \\
Material self & $6 \%$ & $2 \%$ & $3 \%$ & $3 \%$ \\
Physical self & $4 \%$ & $0 \%$ & $1 \%$ & $3 \%$ \\
Activity self & $5 \%$ & $17 \%$ & $17 \%$ & $7 \%$ \\
Perspective self & $0 \%$ & $1 \%$ & $3 \%$ & $15 \%$ \\
Reflexive self & $38 \%$ & $36 \%$ & $26 \%$ & $39 \%$ \\
\hline
\end{tabular}

Results of the Meaning-of-Life Orientations Test were distributed on the five subscales and general level of life orientations. In the analyses of all the groups, the average general level of life orientations dominated. See Table 5.

Table 5. Results of the Meaning-of-Life Orientations Test

\begin{tabular}{ccccc}
\hline & $\begin{array}{c}\text { Ethnic Armenians } \\
\text { in Armenia }\end{array}$ & $\begin{array}{c}\text { Ethnic Armenians } \\
\text { in Russia }\end{array}$ & $\begin{array}{c}\text { Ethnic Russians in } \\
\text { Russia }\end{array}$ & $\begin{array}{c}\text { Ethnic Russians in } \\
\text { Armenia }\end{array}$ \\
\hline \multirow{2}{*}{ High } & $18.18 \%$ & $21.43 \%$ & $32.38 \%$ & $22.38 \%$ \\
Average & $81.82 \%$ & $71.43 \%$ & $53.33 \%$ & $63.33 \%$ \\
Low & $0 \%$ & $7.14 \%$ & $14.29 \%$ & $14.29 \%$ \\
\hline
\end{tabular}

Force, assessment and activity factors were measured in four aspects: real self, ideal self, a typical representative of Armenian nationality, a typical representative of Russian nationality. The results for ethnic Armenians are presented inTable 6. Table 7 presents the results for ethnic Russians.

Table 6. Results for ethnic Armenians in Armenia according to the Personal Semantic Differential method

\begin{tabular}{ccccc}
\hline Factors & Real self & Ideal self & $\begin{array}{c}\text { Typical } \\
\text { representative } \\
\text { of Armenian } \\
\text { nationality }\end{array}$ & $\begin{array}{c}\text { Typical } \\
\text { representative of } \\
\text { Russian nationality }\end{array}$ \\
\hline Assessment & High positive & Low positive & High positive & Low negative \\
Force & Low positive & High positive & Average negative & High positive \\
Activity & High positive & High positive & Average positive & Average positive \\
\hline
\end{tabular}


Table 7. Results for ethnic Russians in Russia according to the Personal Semantic Differential method

\begin{tabular}{ccccc}
\hline Factors & Real self & Ideal self & $\begin{array}{c}\text { Typical representa- } \\
\text { tive of Armenian } \\
\text { nationality }\end{array}$ & $\begin{array}{c}\text { Typical repre- } \\
\text { sentative of Russian } \\
\text { nationality }\end{array}$ \\
\hline Assessment & Average positive & High positive & Low positive & High positive \\
Force & High positive & Average positive & Average negative & Low positive \\
Activity & Low positive & High positive & High positive & Low positive \\
\hline
\end{tabular}

\section{Statistics}

We conducted a correlation analysis in order either to confirm or to challenge our hypothesis. We obtained two statistically significant results. First, there was a statistically important link between male and female respondents; Pearson chisquare $=0.869$, Sig. $=0.000$, indicating a high correlation between these groups. High values of social self - in particular, national-civic identity - as reported by the Armenian and Russian youth when describing themselves, correlated with high and medium levels of general life orientations; Spearman correlation $=0.847$, Sig $=0.002$. Thus our general hypothesis was confirmed.

\section{Discussion}

The data allow us to identify common signs of the personal-semantic aspect of selfunderstanding of one's ethnocultural identity both within the studied ethnic group and under different conditions - in the country of origin and in diaspora.

Ethnocultural traditions and value orientations were in the most important position in the personal-semantic aspect of the students' self-understanding of their ethnocultural identity in diaspora; they are perceived as a way to preserve ethnocultural identity and the reproduction of ethnicity.

The study revealed normative-evaluative features of the self-understanding of ethnocultural identity in the ethnic Armenians in Armenia and in Russia. A comparative analysis of the results allowed us to distinguish the following general features of Armenians' ethnocultural identity in both groups:

- Extrovert and collectivist features made up the core of the Armenians' ethnic normativity, but the listed qualities in the diaspora group were directed primarily at members of their own ethnic community.

- Patriotism was an important part of the ethnocultural ideal in the diaspora group; it was seen simultaneously as ethnic patriotism and as state patriotism, positions that complemented each other.

- Respect for elders was a significant feature of the ethnocultural ideal; it underlay the preservation of the community's ethnocultural identity.

The studied problem was relevant, as knowledge of the specifics of self-understanding enables prediction of a person's behavior in interpersonal contacts; a 
person's resource capabilities depend on self-assessment of the adequacy and the degree of personal responsibility in the self-consciousness structure.

Psychological support when violations of a person's ethnic identity occur would solve a wide range of problems: adaptation, acculturation, interethnic communicative interaction, ethnic tolerance.

\section{Conclusions}

Based on analysis of the results of our study, we have formulated the following conclusions:

1. The content of ethnocultural identity is a process of the integration and identification of distribution bases; such a process is caused by a subconscious desire for unity with the environment through integration in the cultural and symbolic sphere.

2. The ethnopsychological and normative-evaluative standards of a specific ethnic group are demonstratively and clearly manifested exactly in its youth, and, especially important for our purposes, the ethnic worldview and self-consciousness of youth contain the greatest potential for further development of ethnopsychological competence through a set of competent and professionally constructed training programs of ethnopsychological competence. Positive ethnic identity with high value indicators is particularly important to create a positive self-image; it assumes a positive attitude toward other ethnic groups.

3. The majority of respondents in the focus groups noted positive emotions in connection with their being Armenian or Russian. However, ethnic Russians in Armenia pointed out the ease of interaction with Russian speakers, regardless of ethnicity, but noted the difficulty of social interaction caused by their insufficient knowledge of the Armenian language.

4. High values of social self - in particular, national-civic identity - as evidenced by Armenian and Russian youth when describing their ethnicity, correlate with high and medium levels of general life orientations.

5. According to the Personal Semantic Differential method, there were no significant differences between the two groups in the factors of force and activity.

6. When describing themselves, the ethnic Armenian youth didn't use the component of the "past," which was associated with high levels of anxiety. In our opinion, this is due to the Armenian Genocide, an unexamined trauma.

7. The cognitive and affective components of the national identity of the Armenian and Russian students stipulate the adoption of national heroes as a reference group (for the majority of respondents).

8. Insufficient knowledge of traditions was revealed in the group of ethnic Armenians in Armenia, in contrast with the Armenians in Russia. In some cases, they interpreted some native Armenian traditions and rituals in different ways and maintained, in particular, the tradition of the wedding. Keeping traditions as well as performing rituals was important, rather than 
gaining a semantic understanding of these traditions. The overwhelming majority (85\%) of the ethnic Armenians in Armenia had knowledge of the history of Armenia at an above-average level, while the ethnic Armenians in Russia had average knowledge of the history (knowledge only of important dates). Gender differences in the two groups of respondents were not found.

9. Because ethnic Armenians and ethnic Russians are in continuous interaction in Armenia and in Russia, there are positive ethnic attitudes in both groups: tolerance for other ethnic groups, solidarity. This interaction enriches the representatives of both ethnic groups at the regulatory value level, making them carriers of both cultures. Complex programs for the development of the ethnic consciousness of youth should be directed not only at self-diagnosis but also at the development of moral values, national and civic identity, patriotism, a sense of belonging and ownership of what is happening in their country and around the world, teamwork, an understanding of the compatibility of interests, and other important ethnopsychological value orientations.

10. The study of the diversity of national identity as a socio-cultural phenomenon is a general humanitarian responsibility at the intersection of philosophy, psychology, and sociology.

\section{Limitations and future research}

First, the definition of ethnic identity in this article is the most important indicator of the continuity of self-concept, which is integrated into the social environment. Actualization of a subject's understanding of certain aspects of identity is related to the demands of the socio-cultural community, which perceives this type of identity as a problem. The direction of future research could include behavior strategies, awareness of personal and social identity, and comprehension of the self in the structure of self-concept in different social contexts in post-Soviet space.

Second, the historical experience is an integral part of national identity, as a sense of complicity in the historical process determines the consciousness of belonging to a nation as a unified community. In the future, our research may include the following aspects: (1) historical experience as a kind of existential experience; (2) historical experience's role in the formation of national identity and self-understanding (based on the study of Armenian and Russian youth).Such research will make it possible to identify common trends and characteristics of the formation of historical experience as well as its influence on the formation of national identity.

\section{Acknowledgments}

Our study was carried out with the financial support of the State Science Committee of MES RA within the framework of the Armenian-Russian joint scientific project "The psychological aspect of the personality's self-understanding of the formation of national identity in the context of the historical experience in post-Soviet space (based on research of Russian and Armenian youth)". 


\section{References}

Abakumova, I. V. Obuchenie i smysl: smycloobrazovanie v uchebnom processe (Psykhologo-didakticheskii podkhod) [Education and meaning: meaning formation in educational process. Psychological-didactic approach]. Rostov-on-Don: Publishing house of Rostov State University, 2003.

Asmolov, A. G. (2007). Psikhologiya lichnosti: Kulturno-istoricheskoe ponimanie razvitiya cheloveka [The psychology of personality: The cultural-historical understanding of human development]. Moscow: Smisl.

Berberyan, A. S. (2012). Issledovanie samoponimaniya etnokulturnoi identichnosti rossiiskoi i armyanskoi molodejyu [A study of the self-understanding of ethnic and cultural identity in Russian and Armenian youth]. Sociosphera, 4, 78-82. Retrieved from http://www. sociosphera.com/publication/journal/2012/172/issledovanie_samoponimaniya_etnokulturnoj_identichnosti_rossijskoj_i_armyanskoj_molodezhyu

Berberyan, A. S, \& Tuchina, O. R. (2014) Issledovanie osobennostei samointerpretacii lichnosti $v$ razlichnykh etnicheskikh obshnostyakh [Study of personality's self-interpretation features in different ethnic communities]. Chelovek. Soobshestvo. Upravlenie [Person. Community. Management], 1, 86-100. Retrieved from http://chsu.kubsu.ru/arhiv/2014_1/2014_1_BerberyanTuchina.pdf

Bowlby, J. (1969). Attachment and loss (2nd ed.).New York: Basic Books.

Bratchenko, S.L. (2001). Ekzistencialnaya psikhologiya glubinnogo obsheniya. Uroki Jeimsa Byudjentala [The existential psychology of deep communication. James Bugental's lessons]. Moscow: Smisl.

Erikson, E. H. (1968). Identity: Youth and crisis. New York: Norton.

Frankl, V. (1992). Man's search for meaning (4th ed.). Boston: Beacon Press.

Guntrip, H. (1971). Psychoanalytic theory, therapy, and the self: A basic guide to the human personality in Freud, Erikson, Klein, Sullivan, Fairbairn, Hartmann, Jacobson, and Winnicott. New York: Basic Books.

Krisko, V. G. (2008). Etnicheskaya psixologiya [Ethnic psychology]. Moscow: Akademiya.

Lebedeva, N. M., \& Tatarko, A. N. (2011). Metodi etnicheskoi I krosskulturnoi psixologii [Methods of ethnic and cross-cultural psychology]. Moscow: IzdatelstvoVisshei Shkoli Ekonomiki.

Leontiev, A. N. (1975). Deyatelnost. Soznanie.Lichnost [Activity. Conscience. Personality]. Moscow: Politizdat.

Leontiev, D. A. (2003). Psikhologiya smisla: Priroda, stroenie I dinamika smislovoi realnosti [The psychology of meaning: The nature, structure and dynamics of the sense of reality]. Moscow: Smisl.

Marcia, J. E., Waterman, A. S., Matteson, D. R., Archer, S. L., \& Orlofsky, J. L. (1993). Ego identity: A handbook for psychosocial research. New York: Springer-Verlag. doi: 10.1007/978-1-46138330-7

Nalchajyan, A. A. (2010). Psikhologicheskaya adaptaciya [Psychological adaptation]. Moscow: Eksmo.

Pochebut, L. G. (2012). Kross-kulturnaya i etnicheskaya psikhologiya[Cross-cultural and ethnic psychology]. Saint Petersburg: Piter.

Rogers, C. (1959). A theory of therapy, personality and interpersonal relationships as developed in the client-centered framework. In S. Koch (Ed.), Psychology: A study of a science (Vol. 3: Formulations of the person and the social context; 184-225). New York: McGraw-Hill.

Shpet, G. G. (1996).Vvedenie v etnicheskuyu psikhologiyu [Introduction to ethnic psychology]. Saint Petersburg: P.E.T. Alesya. 
Soldatova, G. U. (1998). Psikhologiya mejetnicheskoi napryajennosti [The psychology of ethnic tensions]. Moscow: Smysl.

Stefanenko, T. G. (2000). Etnopsikhologiya [Ethnopsychology] (4th ed.). Moscow: Aspekt Press.

Sullivan, H. S. (2000). Psychiatry: Introduction to the study of interpersonal relations. Psychiatry: Interpersonal and Biological Processes, 63(2), 113-126. (Original work published 1949)

Vygotsky, L. S. (2005). Psikhologiya razvitiya cheloveka [The psychology of human development]. Moscow: Smisl.

Waterman, A. S. (1999). Identity, the identity statuses, and identity status development: A contemporary statement. Developmental Review, 19, 591-621. doi: 10.1006/drev.1999.0493

Znakov, V. V. (2000). Ponimanie subjektom mira kak problema psikhologii chelovecheskogo bytija [Subject understanding of the world as a problem of psychology of human being]. In A.V. Brushlinskii, M.I. Volovikova, \& V.N. Drujinin The problem of subject in psychology (Eds.). (pp. 86-105). Moscow: Akademicheskii proekt.

Original manuscript received July 14, 2015 Revised manuscript accepted February 10, 2016

First published online March 30, 2016 